\title{
Characteristics of White-Footed Mice in Woodland and Grassland in Eastern Massachusetts
}

\author{
Gregory H. ADLER, Lawrence M. REICH ${ }^{1}$ \& Robert H. TAMARIN
}

\begin{abstract}
Adler G. H., Reich L. M. \& Tamarin R. H., 1984: Characteristics of white-footed mice in woodland and grassland in eastern Massachusetts. Acta theriol., 29, 5: 57-62 [With 2 Tables \& 1 Fig.]

Characteristics of white-footed mice, Peromyscus leucopus (Rafinesque, 1818) inhabiting a woodland and an adjacent grassland in eastern Massachusetts (USA) were compared. Mice occurred predominantly in the woodland. The occurrence of mice in the grassland was unrelated to potential competitors, but was instead related to the density of Peromyscus. Mice in the woodland and grassland were similar in terms of sex ratio and reproductive condition, but grassland mice were smaller and had a lower multiple capture rate. It is hypothesized that grassland Peromyscus in this study were predominantly dispersing mice and that the grassland functioned as a dispersal sink. Mice in the study area are contrasted with those in coastal southeastern Massachusetts which maintain fairly stable resident populations in grasslands.
\end{abstract}

[Dept. Biol., Boston Univ., Boston, Ma 02215, USA]

\section{INTRODUCTION}

The white-footed mouse (Peromyscus leucopus (Rafinesque, 1818)) is common in the forests of the northeastern United States (Baker, 1968). It also occurs in lesser numbers in grasslands where it has been found to maintain resident populations (Adler \& Tamarin, 1984). A number of studies have dealt with the population biology of $P$. leucopus in woodland or grassland, and Batzli (1977) compared the population dynamics and demography of white-footed mice in floodplain and upland forests. However, we know of no studies which have compared characteristics of $P$. leucopus in woodland and grassland.

The present study compares demographic and reproductive attributes of $P$. leucopus in a mixed deciduous-coniferous woodland and an adjacent grassland.

\section{MATERIALS AND METHODS}

Live-trapping was conducted from August 1978 to June 1982 in a grassy field and an adjacent mixed deciduous-coniferous woodland at the Broadmoor/Little Pond Audubon Sanctuary, South Natick, Massachusetts (USA).

1 Present address: Dept. Zool., Tel Aviv Univ., Ramat Aviv, Tel Aviv, Israel 
A 1 ha rectangular trapping grid consisting of 118 trap stations was established with stations located $7.6 \mathrm{~m}$ apart. 100 trap stations were located in the grassland. The woodland and grassland stations were separated by a $15.2 \mathrm{~m}$ buffer strip where no traps were set. Each trap station was occupied by a Ketch-all multiplecapture live-trap (Kness Mfg. Co., Albia, Iowa, USA) baited with oats and supplied with cotton for bedding.

Captured mice were ear-tagged with fingerling fish tags, weighed, and sexed. Reproductive data were collected and consisted of position of the testes (scrotal or abdominal) in males and vaginal patency, size of the nipples, and openness of the pubic symphysis in females. Obvious pregnancies were detected by palpation. Mice were released at their point of capture after data were recorded.

Traps were set for two consecutive nights and checked the following mornings. Traps were left in place unset after each trapping session, and trapping was conducted monthly.

\section{RESULTS}

\subsection{Density Trends and Breeding Seasons}

Densities were estimated as the minimum number alive to avoid the biases of mark-recapture statistics (Krebs, 1966). Density trends were similar to other Peromyscus populations in eastern Massachusetts (Adler \& Tamarin, 1983) with numbers generaly highest in autumn and winter and lowest in spring (Fig. 1).

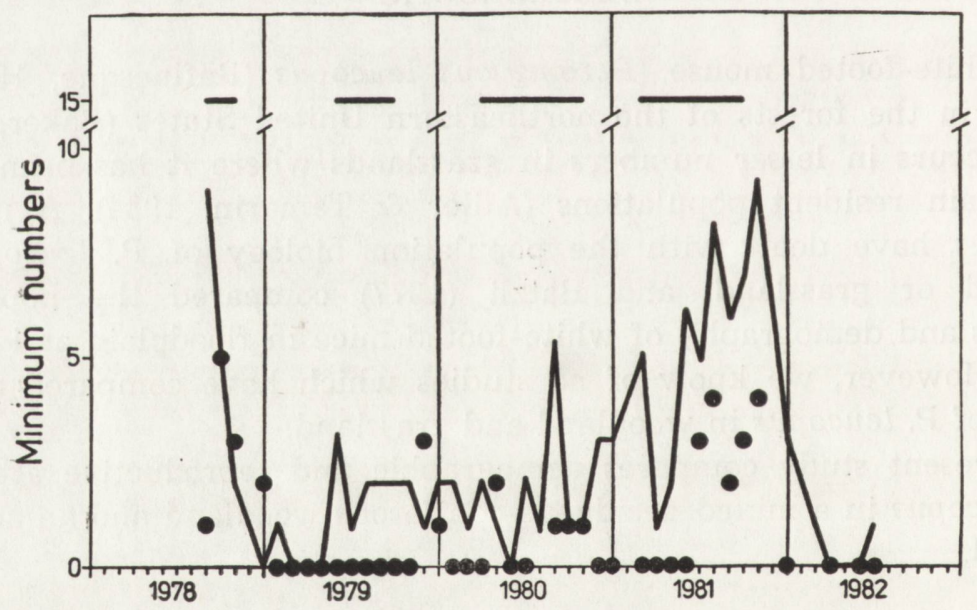

Fig. 1. Densities and breeding seasons of Peromyscus leucopus in woodland and grassland. The curve represents the density of mice in the woodland and the solid data points represent the density of mice in the grassland. Breeding seasons are indicated by the horizontal bars at the top of the graph.

A breeding season was defined as the period between the first and last capture of an individual (male or female) in breeding condition. A male was considered breeding if it had scrotal testes, and a female was 
considered breeding if it had a patent vagina or enlarged nipples or was pregnant. Breeding commenced in late winter or spring (February to May) and ended in late summer (September or October) (Fig. 1).

\subsection{Habitat Selection}

126 captures of 68 individuals were recorded in the 18 woodland traps and 44 captures of 29 individuals were recorded in the 100 grassland traps. Only 3 individuals were caught in both habitats. Mice thus showed a clear tendency to occupy the woodland habitat.

To determine what factors may have influenced the occurrence of mice in the grassland habitat, we grouped trapping data into three-month periods (seasons) and correlated with five variables the number of grassland captures and the proportion of total captures which the grassland contributed (Table 1). The number of grassland captures was

Table 1

Correlation matrix of grassland captures (as number and proportions) and 5 variables potentially affecting the distribution of Peromyscus in the grassland. Data were grouped into 3 -month periods (seasons). $\mathrm{N}=17$ periods.

\begin{tabular}{|c|c|c|c|c|}
\hline Season & $\begin{array}{c}\text { Number of } \\
\text { woodland captures }\end{array}$ & $\begin{array}{l}\text { Peromyscus } \\
\text { density }\end{array}$ & $\begin{array}{c}\text { Microtus } \\
\text { density }\end{array}$ & $\begin{array}{l}\text { Zapus } \\
\text { density }\end{array}$ \\
\hline \multicolumn{5}{|c|}{ Number of grassland captures } \\
\hline .4718 & \multirow{2}{*}{$\begin{array}{l}.6905 \\
\text { Grassland captures } \\
-.0844\end{array}$} & $\begin{array}{l}.8692^{2} \\
\text { as proportio }\end{array}$ & $\begin{array}{l}.0822 \\
\text { otal captures }\end{array}$ & .3146 \\
\hline .0120 & & $\begin{array}{c}s \text { as proportio } \\
.1662\end{array}$ & $\begin{array}{l}\text { total captures } \\
\quad .2257\end{array}$ & -.2125 \\
\hline
\end{tabular}

${ }^{1} p<.01,{ }^{2} p<.001$

correlated with the number of woodland captures and the total density of Peromyscus (woodland and grassland combined), yet the proportion of captures contributed by the grassland was independent of the five variables.

\subsection{Sex Ratios, Body Weights, and Reproduction}

To determine if there were differences in the characteristics of mice in the two habitats, we examined sex ratios, body weights, and reproductive condition of mice occurring only in the woodland with those occurring only in the grassland.

The sex ratio (males per female) of mice in the grassland, calculated as the minimum number alive summed over the entire study, was $0.65(\mathrm{~N}=36)$ and in the woodland was $1.23(\mathrm{~N}=105)$. This difference is not statistically significant $\left(\chi^{2}=2.87, p \geqslant .05\right)$. We computed mean body 
weights over the entire study (Table 2) and found males and females to be heavier in the woodland $(F=7.45, p<.01)$. No differences were found between the sexes $(F=0.62, p \geqslant .25)$. We compared the numbers of males and females in breeding condition, summed over all breeding seasons, using Fisher's exact probability test (Siegel, 1956). We found no differences in the proportions of males and females breeding between the two habitats: $70.0^{\circ} \%(\mathrm{~N}=40)$ of all males were breeding in the woodland and $62.5 \%(\mathrm{~N}=8)$ of all males were breeding in the grassland (exact $p=.80) ; 60.6 \%(\mathrm{~N}=33)$ of all females were breeding in the woodland and $46.7 \%(\mathrm{~N}=15)$ of all females were breeding in the grassland (exact $p=.28$ ).

Table 2

Body weights of Peromyscus in the woodland and grassland habitats. Means \pm 1 standard deviation are given, with sample sizes in parentheses.

\begin{tabular}{|c|c|c|}
\hline & Males & Females \\
\hline Woodland & $19.57 \pm 3.99$ & $19.37 \pm 4.58$ (41) \\
\hline Grassland & $16.27 \pm 2.49$ & $17.86 \pm 4.18$ \\
\hline
\end{tabular}

\subsection{Multiple Captures}

Since multiple-capture traps were used in this study, we compared the incidences of multiple captures in the woodland and grassland. 20 double captures and 2 triple captures were recorded in the woodland, giving a multiple-capture rate of $37.7 \%$. Only 2 double captures were recorded in the grassland, giving a multiple-capture rate of $9.5 \%$. The difference in multiple-capture rates between the 2 habitats is statistically significant $\left(\chi^{2}=7.04, p<.01\right)$.

\section{DISCUSSION}

In this study, we have shown that Peromyscus leucopus occupied the woodland habitat to a much greater degree than the grassland habitat. Two other species of small rodents were common in the grassland, the meadow vole (Microtus pennsylvanicus (Ord, 1815)) and the meadow jumping mouse (Zapus hursonicus Zimmermann, 1780). If these two species competitively interfered with Peromyscus and excluded them from the grassland, then there should be a negative relationship between the densities of these two species and the occurrence of Peromyscus in the grasiland. However, we found no such relationship. Instead, we found the occurrence of Peromyscus in the grassland to be related to the density of Peromyscus. 
Grassland Peromyscus were lower in body weight and had a lower multiple capture rate than woodland Peromyscus. The relationship between Peromyscus in the grassland and the woodland in terms of numbers and body weights are similar to the relationship between resident and dispersing $P$. leucopus in Massachusetts (Adler \& Tamarin, ms.) and small mammals in general (Gaines \& McClenaghan, 1980). In particular, the number of dispersers is usually correlated with population density, and dispersing Peromyscus are usually younger (smaller) subordinate mice (Fairbairn, 1978a; 1978b). Thus, mice in the grassland were predominantly young mice which may have been dispersing, and the grassland may have functioned as a dispersal sink (Lidicker, 1975). Sullivan (1979), Van Horn (1981), and Martell (1983) suggested that clearcut areas in British Columbia, Alaska, and Ontario, respectively, function as dispersal sinks for P. maniculatus (Wagner, 1845).

Adler \& Tamarin (1983) described the demography of P. leucopus in grasslands in coastal southeastern Massachusetts. Although these mice were found in grasslands, they maintained fairly stable resident populations and displayed characteristics similar to mice in the woodland in the present study. Thus, $P$. leucopus is able to maintain resident populations in grassland in coastal southeastern Massachusetts, but occurs in grasslands in more interior Massachusetts mostly as dispersing individuals. The question of why Peromyscus occupy grasslands differentially in Massachusetts warrants further investigation.

\section{REFERENCES}

1. Adler G. H. \& Tamarin R. H., 1984: Demography and reproduction in island and mainland white-footed mice (Peromyscus leucopus) in southeastern Massachusetts. Can. J. Zool., in press.

2. Baker R. H., 1968: Habitats and distribution. [In: "Biology of Peromyscus (Rodentia)". J. A. King ed.]. Am. Soc. Mammal. Publ. No. 2: 98-126.

3. Batzli G. O., 1977: Population dynamics of the white-footed mouse in floodplain and upland forests. Am. Midl. Nat., 97: 18-32.

4. Fairbairn D. J., 1978a: Dispersal of deer mice, Peromyscus maniculatus: proximal causes and effects on fitness. Oecologia, 32: 171-193.

5. Fairbairn D. J., 1978b: Behavior of dispersing deer mice (Peromyscus maniculatus). Behav. Ecol. Sociobiol., 3: 265-282.

6. Gaines M. S. \& McClenaghan Jr., 1980: Dispersal in small mammals. Ann. Rev. Ecol. Syst., 11: 163-196.

7. Krebs C. J., 1966: Demographic changes in fluctuating populations of Microtus californicus. Ecol. Monogr., 36: 239-273.

8. Lidicker W. Z., 1975: The role of dispersal in the demography of small mammals. [In: "Small mammals: their productivity and population dynamics". F. B. Golley, K. Petrusewicz, L. Ryszkowski, eds.]. Cambridge Univ. Press: 103-134. Cambridge. 
9. Martell A. M., 1983: Demography of southern red-backed voles (Clethrionomys gapperi) and deer mice (Peromyscus maniculatus) after logging in north-central Ontario. Can. J. Zool., 61: 958-969.

10. Siegel S., 1956: Non-parametric statistics for the behavioral sciences. McGraw Hill Book Co.: 1-312. New York.

11. Sullivan T. P., 1979: Demography of populations of deer mice in coastal forest and clear-cut (logged) habitats. Can. J. Zool., 57: 1636-1648.

12. Van Horn B., 1981: Demography of Peromyscus maniculatus populations in seral stages of coastal coniferous forest in southeast Alaska. Can. J. Zool., 59: $1045-1061$.

Accepted, November 16, 1983.

\section{Gregory H. ADLER, Lawrence M. REICH i Robert H. TAMARIN}

\section{CHARAKTERYSTYKA PEROMYSCUS LEUCOPUS ZAMIESZKUJAZCYCH LASY I ŁĄKI WSCHODNIEGO MASSACHUSETTS}

\section{Streszczenie}

Od sierpnia 1978 do czerwca 1982 badano demograficzne i reprodukcyjne cechy populacji myszaków Peromyscus leucopus, zamieszkujących lasy mieszane i przylegające do nich łąki. Odłowy prowadzono przy pomocy żywołówek wielołownych. Złowione osobniki znakowano, ważono i określano płeć, aktywnść, wielkość sutek itp. i wypuszczano w miejscu złowienia. Stwierdzono, że zagęszczenia były podobne jak u innych populacji Peromyscus we wschodnim Massachusetts, z najwyższą liczebnością w jesieni i zimie a najniższą na wiosnę (Ryc. 1). W celu określenia jakie czynniki wpływają na występowanie myszaków na łąkach przeprowadzono analizę statystyczną danych $\mathrm{z}$ odłowów pogrupowanych $\mathrm{w}$ okresy 3-miesięczne (Tabela 1). Stwierdzono, że występowanie myszaków na łakach zależy od liczebności populacji leśnej. Myszaki z lasów i łąk miały podobny stosunek płci i rozród (Tabela 2), lecz „łąkowe” były lżejsze i miały niższy współczynnik łowności. Autorzy przypuszczają, że łąki są środowiskiem zajmowanym przez migrujące osobniki Peromyscus. Sytuacja na badanym terenie jest odmienna od sytuacji z wybrzeży połudn.-wschodniego Massachusetts, gdzie utrzymuje się osiadła populacja na łąkach. 